\title{
Penurunan Keluhan Nyeri Pinggang Pada Ibu Hamil menggunakan M-Health Di Puskesmas Ibrahim Adjie Kota Bandung
}

\author{
Linda Rofiasari ${ }^{1 *}$, Anita D. Anwar ${ }^{2}$, Vita Muniarti T ${ }^{2}$, Herry Herman ${ }^{3}$, Johanes \\ C.Mose $^{2}$, Ahmad Rizal ${ }^{4}$ \\ ${ }^{1}$ Fakultas Ilmu Kesehatan Universitas Bhakti Kencana \\ ${ }^{2}$ Departemen Obstetri dan Ginekologi Fakultas Kedokteran Universitas Padjadjaran \\ ${ }^{3}$ Departemen Ortopedi Fakultas Kedokteran Universitas Padjajaran \\ ${ }^{4}$ Departemen Neurologi Fakultas Kedokteran Universitas Padjajaran \\ Corresponding author: Linda Rofiasari (lindarofiasari@yahoo.com) \\ Received: Mei, 20 2020; Accepted: June, 28 2020; Published: September, 12020
}

\begin{abstract}
ABSTRAK
Penelitian ini bertujuan untuk menganalisis pengaruh penerapan Aplikasi Sahabat Ibu Hamil (ASIH) terhadap penurunan keluhan nyeri pinggang pada usia kehamilan 24 sampai dengan 30 minggu.

Metode penelitian ini secara kuantitatif dengan studi true experiment dengan teknik pre-post test with control group design terhadap $62 \mathrm{ibu}$ hamil pada kedua kelompok penggunaan ASIH dan metode konvensional (Buku KIA dan Konseling Bidan) dengan tekhnik Ramdom Blok Permutasi. Penelitian dilakukan di Puskesmas Ibrahim Adjie Kota Bandung pada bulan November sampai dengan Desember 2016 dengan menggunakan instrument penilaian nyeri Visual Analog Scale (VAS). Analisis data yang digunakan adalah Chi square.

Hasil penelitian menunjukkan bahwa pada kelompok intervensi (ASIH) terdapat 19 orang (61,3 $\%$ ) mengalami penurunan skor nyeri dari 31 responden, sedangkan pada kelompok non ASIH (kontrol) dari 31 orang hanya 11 orang $(35,5 \%)$ mengalami penurunan skor nyeri. Hasil analisis statistik dengan uji Chi-kuadrat diperoleh nilai $\mathrm{p}=0,042(\mathrm{p}<0,05)$ yang bermakna dengan hasil NNT bahwa diperlukan 4 orang yang diberikan Aplikasi Sahabat Ibu Hamil (ASIH) diharapkan menurunkan keluhan nyeri pinggang pada 1 orang.

Hasil penelitian menunjukkan bahwa terdapat pengaruh penerapan Aplikasi Sahabat Ibu Hamil (ASIH) terhadap penurunan keluhan nyeri pinggang pada usia kehamilan 24 sampai dengan 30 minggu.
\end{abstract}

Kata Kunci: Aplikasi Sahabat Ibu Hamil (ASIH), Nyeri Pinggang, Ibu Hamil

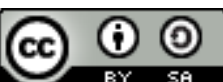

This is an open-acces article distributed under the terms of the Creative Commons Attribution-ShareAlike 4.0 International License.

\section{PENDAHULUAN}

Pembangunan kesehatan Indonesia diarahkan pada pencapaian Indonesia sehat yaitu terciptanya masyarakat dengan perilaku yang sehat, memiliki kemampuan untuk menjangkau pelayanan kesehatan dan derajat kesehatan yang bermutu, adil dan merata, yang dirumuskan berdasarkan arah pembangunan global dalam Sustainable Development Goals (SDGs). Salah 
satu target SDGs adalah meningkatkan kualitas pelayanan kesehatan. Kualitas pelayanan merupakan upaya untuk mempertahankan mutu pelayanan kebidanan terhadap klien sebagai pelanggan dalam memberikan informasi pelayanan kesehatan yang dituntut untuk membangun loyalitas dengan baik dari tenaga kesehatan. ${ }^{1-2} \quad$ Kehamilan merupakan peristiwa alamiah yang normal, namun pada masa ini terjadi perubahan hormon kehamilan yang dapat menimbulkan perubahan anatomi dan fisiologis ibu hamil. Pertumbuhan dan perkembangan kehamilan diperlukan kemampuan ibu hamil untuk beradaptasi dengan perubahan-perubahan fisik maupun psikologis yang dapat menimbulkan ketidaknyamanan dan mengganggu aktifitas ibu sehari-hari, sehingga diperlukan pengawasan selama kehamilan. ${ }^{3-6}$

Salah satu ketidaknyamanan yang sering timbul dalam masa kehamilan adalah nyeri pinggang yang tidak hanya terjadi pada trimester tertentu, namun dapat dialami sepanjang masa kehamilan terutama pada trimester ketiga. Kejadian nyeri pinggang pada kehamilan dialami 7 dari $10 \mathrm{ibu} \mathrm{hamil}{ }^{7}$ Faktor penyebab terjadinya nyeri pinggang pada masa kehamilan meliputi pertumbuhan uterus yang dapat menyebabkan perubahan postur tubuh ibu, penambahan berat badan. Pertumbuhan uterus sejalan dengan perkembangan kehamilan mengakibatkan teregangnya ligamen penopang yang dirasakan ibu sebagai spasme menusuk yang sangat nyeri yang sering disebut nyeri ligamen. Hal ini yang menyebabkan terjadinya nyeri pinggang. Jika keluhan nyeri pinggang tidak ditangani dengan tepat dapat menyebabkan nyeri pinggang jangka panjang, meningkatkan kecenderungan nyeri pinggang postpartum dan nyeri pinggang kronis yang akan lebih sulit untuk diobati atau disembuhkan. ${ }^{6-7}$

Upaya untuk memantau pertumbuhan selama kehamilan yaitu dengan asuhan kehamilan berkualitas. $^{8-9}$ Namun Ibu hamil kebanyakan kesulitan mengatasi ketidaknyamanan fisik maupun psikologis. ${ }^{9}$ Mereka membutuhkan dukungan baik dari tenaga kesehatan maupun keluarga. Salah satu upaya pemerintah untuk meningkatkan kesehatan ibu hamil adalah dengan memberikan informasi kesehatan melalui media cetak yaitu Buku Kesehatan Ibu dan Anak (Buku KIA). ${ }^{10}$ Buku KIA merupakan alat informasi, edukasi dan komunikasi dalam menyebarkan informasi penting mengenai Kesehatan Ibu dan Anak kepada keluarga. Buku KIA berpotensial meningkatkan pengetahuan sebanyak $56 \%$ dan perilaku keluarga/ibu mengenai kesehatan reproduksi dan kesehatan anak. ${ }^{11}$ Namun, Buku KIA saat ini memiliki kelemahan baik dari segi konten maupun dari segi pengadaannya, keterbatasan informasi yang tersedia tentang kehamilan, mudah rusak dan sering hilang sehingga membuat buku KIA tidak efektif dibandingkan dengan media elektronik yang banyak dikembangkan saat ini. ${ }^{11-12}$

Berdasarkan hasil studi pendahuluan di beberapa Bidan Praktik Mandiri (BPM) di Wilayah Puskesmas yang ada di Kota dan Kabupaten Aceh, Riau, Jawa Barat, Jawa Tengah dan Banten terhadap 64 ibu hamil, didapatkan bahwa 91,6\% ibu hamil jika ada keluhan akan memeriksakan diri ke bidan, namun sebanyak 53,1\% ibu hamil merasa tidak yakin dapat mengatasi ketidaknyamanan atau keluhan dalam kehamilan, sehingga sebanyak 5,4\% ibu hamil mengatakan keluhan tidak berkurang. Hal ini dapat disebabkan karena masih terdapat $8 \%$ ibu hamil tidak menerapkan saran-saran yang disampaikan oleh bidan. Hasil wawancara menyatakan bahwa informasi kesehatan yang telah diberikan oleh bidan pada kunjungan ANC belum dapat meningkatkan pengetahuan ibu untuk melakukan upaya perawatan diri mengatasi ketidaknyamanan secara mandiri, sehingga ada kecenderungan ibu hamil akan berperilaku sesuai informasi lain.

Peran bidan sangat diperlukan dalam perawatan kehamilan, penjelasan dan konseling dari bidan tentang perubahan fisiologi diharapkan ibu hamil dapat menerima perubahan tersebut, namun kenyataan banyak ibu hamil tidak mendapatkan informasi tersebut dari bidan. ${ }^{13-15}$

Salah satu faktor yang memengaruhi perawatan kehamilan adalah pengetahuan ibu hamil, informasi yang tidak sesuai dengan harapan menimbulkan ketidakpuasan terhadap pelayanan antenatal. Hal ini sesuai hasil penelitian yang menyatakan bahwa setiap kunjungan antenatal bidan gagal untuk memberikan informasi yang cukup mengenai kondisi ibu hamil, sehingga 
keluhan yang dirasakan tidak teratasi. Hal ini didukung juga dengan hasil penelitian lain yang menyatakan bahwa yang berkontribusi paling banyak mengenai ketidakpuasan pasien terhadap layanan antenatal yaitu kurangnya informasi yang diberikan bidan mengenai kehamilan sehingga ibu tidak dapat mengatasi keluhan yang dirasakan. ${ }^{16-17}$

Kepuasan pasien dalam menerima pelayanan kesehatan mencakup beberapa hal, salah satunya adalah komunikasi antara bidan dan pasien. ${ }^{18}$ Namun kenyataan kualitas ketrampilan bidan dalam berkomunikasi dan memberikan konseling masih rendah yang berdampak terhadap transfer pesan kepada pasien kurang baik, bidan kurang peka dan kurang mampu menggali kebutuhan dan masalah pasien, tidak tanggap terhadap perasaan pasien, sehingga pasien merasa tidak puas. ${ }^{16-18}$ Hasil studi pendahuluan menujukkan bahwa $37 \%$ ibu hamil mengatakan informasi yang diberikan bidan selalu sama pada setiap kunjungan dan sebanyak $15,2 \%$ mengatakan tidak puas terhadap informasi yang diberikan, sehingga mendorong sebagian besar ibu hamil mencari informasi lain dari internet.

Perkembangan teknologi informasi pada perangkat bergerak saat ini berkembang pesat. Salah satu perkembangan teknologi yang dapat digunakan adalah smartphone. Hal ini menjadi salah satu sarana bagi ibu hamil untuk memperoleh informasi dalam meningkatkan pendidikan kesehatan. Hal ini didukung oleh hasil penelitian lund S (2014) menyatakan bahwa intervensi dengan menggunakan smartphone secara signifikan dapat meningkatkan kehadiran ibu hamil lebih dari 4 kali kunjungan antenatal (OR 2,39; 95\% CI, 1,03-5,55). Selain itu sebanyak 71\% ibu hamil merasa bahwa pendidikan kesehatan melalui Mobile Phone membantu dalam berbagai bidang termasuk pembelajaran tentang tanda bahaya pada kehamilan. ${ }^{19}$ Rossathum Jareethum MD, dkk (2008) menyatakan bahwa tingkat kepuasan ibu hamil yang didukung dengan menggunakan Short Message Service (SMS) Mobile phone lebih tinggi $(9,25 \%)$ dibanding yang tidak menerima SMS $(8,00 \%)$ selama periode antenatal sehingga dapat meningkatkan kepercayaan dan mengurangi kecemasan ibu hamil. ${ }^{20}$

Pada tahun 2014 jumlah pengguna smartphone sebanyak 45 juta pengguna dan pada tahun 2015 mengalami peningkatan mencapai 56 juta pengguna. Salah satu cara yang dilakukan yaitu dengan memanfaatkan smartphone sebagai alat untuk membantu meningkatkan pengetahuan,

keterampilan dan komunikasi dalam pelayanan kehamilan. Hasil penelitian menunjukkan bahwa intensitas penggunaan smartphone berpengaruh signifikan terhadap perilaku komunikasi sebesar 55,4\%. Hasil studi pendahuluan yang dilakukan diperoleh bahwa 96\% bidan dan $87 \%$ ibu hamil memiliki smartphone berbasis android. Aplikasi smartphone memungkinkan bagi ibu untuk mengakses layanan kesehatan yang mereka butuhkan, membantu pertolongan pertama sekaligus menghubungi tenaga kesehatan dan membantu pengguna untuk menjawab keluhan seputar kehamilan.

Studi pendahuluan yang dilakukan bulan Juni 2016 di Puskesmas Ibrahim Adji Kota Bandung tentang penggunaan smartphone didapat hasil bahwa dari 23 responden ibu hamil sebanyak $15 \mathrm{ibu}$ hamil $(65,2 \%)$ menggunakan dan memahami smartphone, sebanyak $5 \mathrm{ibu}$ hamil $(21,7 \%)$ yang mempunyai tetapi tidak memahami smartphone dan sebanyak 3 ibu hamil (13\%) yang tidak mempunyai smartphone. Sebagian dari ibu mencari informasi tentang keluhannya di internet, Buku KIA dan beberapa ibu hamil membiarkan keluhannya tanpa penanganan dengan alasan tidak mengetahui informasi tentang keluhan yang dirasakan.

\section{METODE}

Penelitian ini menggunakan rancangan true experiment dengan pretest posttest with control group design Subjek penelitian yaitu ibu hamil trimester II yang mengalami keluhan nyeri pinggang di Wilayah Kerja Puskesmas Ibrahim Adjie Kota Bandung sebanyak 62 orang, yang terbagi ke dalam 2 kelompok yaitu kelompok intervensi yaitu ibu hamil yang mendapatkan aplikasi ASIH dan kelompok kontrol yaitu ibu yang menggunakan buku KIA dan konseling bidan untuk menangani keluhan nyeri pinggang. Pengambilan sampel 
berdasarkan teknik simple random sampling dengan teknik blok permutasi. Pengujian statistik menggunakan uji Chi Square dengan kemaknaan hasil uji ditentukan berdasarkan nilai p<0,05.

\section{HASIL}

Tabel 4.1 Karakteristik responden pada kedua kelompok penelitian

\begin{tabular}{|c|c|c|c|c|}
\hline \multirow{2}{*}{\multicolumn{2}{|c|}{ Karakteristik }} & \multicolumn{2}{|c|}{ Kelompok } & \multirow[b]{2}{*}{ Nilai $\mathbf{p}^{*}$} \\
\hline & & Intervensi $(\mathbf{n}=\mathbf{3 1})$ & Kontrol $(\mathrm{n}=31)$ & \\
\hline & Umur ibu (tahun) & & & 0,421 \\
\hline & $<20$ & $0(0 \%)$ & $1(3,2 \%)$ & \\
\hline & $20-34$ & $23(74,2 \%)$ & $28(90,3 \%)$ & \\
\hline & $\geq 35$ & $8(25,8 \%)$ & $2(6,5 \%)$ & \\
\hline & Rerata (SD) & $27,6(6,8)$ & $27,9(4,9)$ & \\
\hline & Median (rentang) & $26(20-40)$ & $28(18-38)$ & \\
\hline \multirow[t]{2}{*}{2.} & Usia kehamilan (Minggu) & & & \\
\hline & Median (rentang) & $27(24-30)$ & $27(24-30)$ & 1,0 \\
\hline \multirow[t]{5}{*}{3.} & Paritas & & & \\
\hline & Primipara & $12(38,7 \%)$ & $9(29,0 \%)$ & \\
\hline & Multipara & $19(61,3 \%)$ & $21(67,7 \%)$ & \\
\hline & Grandemultipara & $0(0 \%)$ & $1(3,2 \%)$ & \\
\hline & Median (rentang) & $2(1-3)$ & $2(1-5)$ & 0,675 \\
\hline \multirow[t]{4}{*}{4.} & Pendidikan & & & 0,758 \\
\hline & SMP & $3(9,7 \%)$ & $4(12,9 \%)$ & \\
\hline & SMU & $27(87,1 \%)$ & $25(80,6 \%)$ & \\
\hline & $\mathrm{Ak} / \mathrm{PT}$ & $1(3,2 \%)$ & $2(6,5 \%)$ & \\
\hline \multirow[t]{3}{*}{5.} & Pekerjaan & & & 0,612 \\
\hline & Bekerja & $3(9,7 \%)$ & $1(3,2 \%)$ & \\
\hline & Tidak bekerja & $28(90,3 \%)$ & $30(96,8 \%)$ & \\
\hline & Aktivitas sehari-hari & & & 1,0 \\
\hline & Ringan & $4(12,9 \%)$ & $4(12,9 \%)$ & \\
\hline & Sedang & $27(87,1 \%)$ & $27(87,1 \%)$ & \\
\hline \multirow[t]{4}{*}{7.} & Weight gain & & & 0,355 \\
\hline & Rendah & $2(6,5 \%)$ & $0(0 \%)$ & \\
\hline & Normal & $27(87,1 \%)$ & $29(93,5 \%)$ & \\
\hline & Tinggi & $2(6,5 \%)$ & $2(6,5 \%)$ & \\
\hline
\end{tabular}

Keterangan : *) untuk usia, usia kehamilan dan paritas dengan uji Mann-Whitney; untuk pekerjaan,dan aktivitas dengan uji eksak Fisher; pendidikan dan status gizi dengan uji Chi-kuadrat

Berdasarkan tabel 4.1. tampak usia ibu terbanyak pada kelompok 20 sampai 34 tahun masingmasing 23 orang $(74,2 \%)$ pada kelompok intervensi dan 28 orang $(90,3 \%)$ pada kelompok kontrol. Untuk usia kehamilan komposisinya sama yaitu antara 24 sampai 30 minggu dengan median 27 minggu, paritas sebagian besar multipara yaitu 19 orang $(61,3 \%)$ pada kelompok intervensi dan 21 orang $(67,7 \%)$ pada kelompok kontrol. Untuk pendidikan terbanyak SMU masing-masing $27(87,1 \%)$ dan 25 orang $(80,6 \%)$ pada kelompok intervensi dan kontrol, sebagian besar subjek penelitian tidak bekerja yaitu 28 orang $(90,3 \%)$ pada kelompok intervensi dan 30 orang $(96,8 \%)$ pada kelompok kontrol. Status gizi berdasarkan weight gain tampak sebagian besar ada pada kategori normal yaitu 27 orang $(87,1 \%)$ pada kelompok intervensi sebanyak 29 orang $(93,5 \%)$ pada kelompok kontrol. Perbedaan karakteristik subjek pada kedua kelompok ini secara statistik tidak bermakna $(p>0,05)$, dengan homogenitas karakteristik ini maka layak dapat diperbandingkan. 
Tabel 4.2 Perbandingan Penurunan Skor Keluhan Nyeri pinggang (VAS) pada kedua kelompok Penelitian sebelum dan sesudah perlakuan

\begin{tabular}{|c|c|c|c|}
\hline \multirow[b]{2}{*}{ Kategori VAS Pre } & \multicolumn{2}{|c|}{ Kategori VAS Post } & \multirow[b]{2}{*}{ Nilai $p^{*}$} \\
\hline & Ringan & Sedang & \\
\hline ASIH & & & 0,250 \\
\hline 1. Ringan & $20(100 \%)$ & $0(0 \%)$ & \\
\hline 2. Sedang & $3(27,3 \%)$ & $8(72,7 \%)$ & \\
\hline Kontrol & & & 0,250 \\
\hline 1. Ringan & $20(100 \%)$ & $0(0 \%)$ & \\
\hline 2. Sedang & $3(27,3 \%)$ & $8(72,7 \%)$ & \\
\hline
\end{tabular}

Keterangan: *) berdasarkan uji Mc.Nemar

Tabel 4.2 menyajikan kategori keluhan nyeri pinggang saat sebelum perlakukan pada kedua kelompok menunjukkan tidak ada perbedaan yang bermakna dengan nilai $\mathrm{p}>0,05$ yang artinya kedua kelompok dapat dibandingkan. Sedangkan kategori keluhan setelah perlakuan didapatkan nilai $\mathrm{p}>0,05$ yang menunjukkan bahwa tidak terdapat perbedaan bermakna pada kedua kelompok dengan menggunakan uji Mc.Nemar.

Tabel 4.3 Perbandingan Penurunan Skor Keluhan Nyeri pinggang (VAS) pada kedua kelompok Penelitian sebelum dan sesudah perlakuan

\begin{tabular}{|c|c|c|c|}
\hline \multirow[b]{2}{*}{ VAS } & \multicolumn{2}{|c|}{ Kelompok } & \multirow[b]{2}{*}{ Nilai $\mathbf{p}^{*)}$} \\
\hline & $\begin{array}{l}\text { ASIH } \\
(\mathbf{n}=31)\end{array}$ & $\begin{array}{c}\text { Kontrol } \\
(\mathbf{n}=\mathbf{3 1})\end{array}$ & \\
\hline 1. Sebelum intervensi : & & & 0,826 \\
\hline Median & 3 & 3 & \\
\hline Rentang & $1-5$ & $1-5$ & \\
\hline 2. Sesudah intervensi & & & 0,251 \\
\hline Median & 2 & 2 & \\
\hline Rentang & $1-5$ & $1-5$ & \\
\hline $\begin{array}{l}\text { Perbandingan sebelum } \\
\text { dengan sesudah }\end{array}$ & $\mathrm{p}<0,001^{* *}$ & $\mathrm{p}=0,001^{* *}$ & \\
\hline
\end{tabular}

Keterangan : *) berdasarkan uji Mann-Whitney; **) Uji Wilcoxon

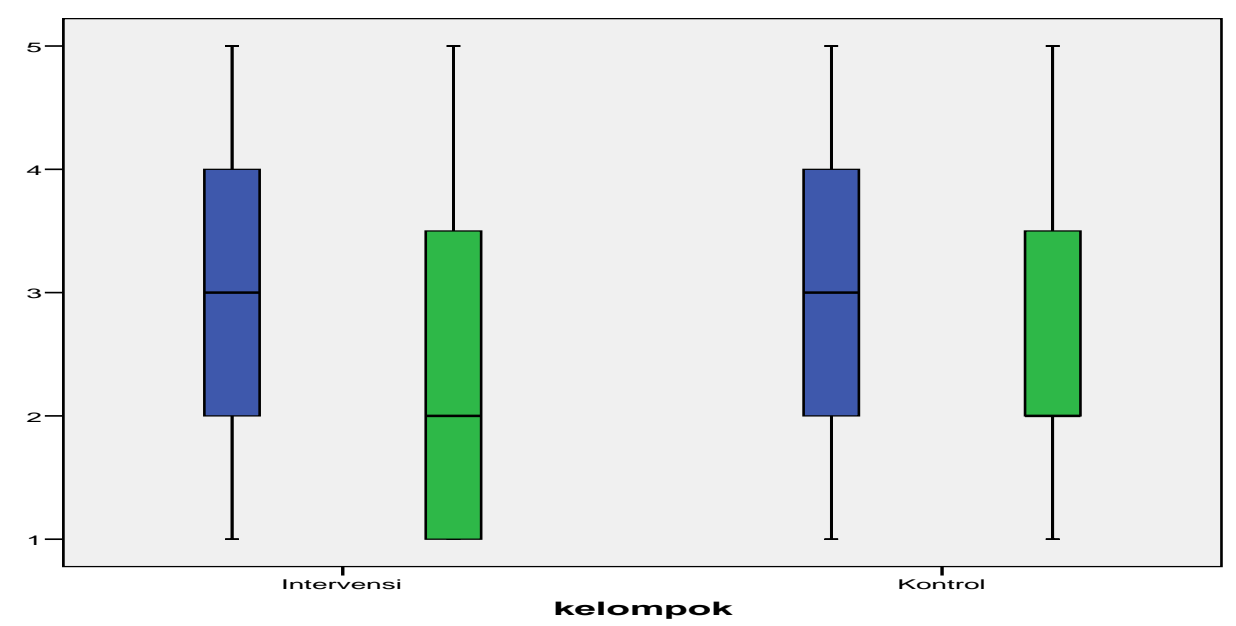

Tabel 4.3 menyajikan skor keluhan nyeri pinggang saat sebelum perlakukan pada kedua kelompok menunjukkan tidak ada perbedaan yang bermakna dengan nilai $p>0,05$ yang artinya kedua kelompok dapat dibandingkan. Sedangkan skor keluhan setelah perlakuan didapatkan nilai $\mathrm{p}>0,05$ yang menunjukkan bahwa tidak terdapat perbedaan bermakna pada kedua kelompok. Jika dibandingkan antara pengamatan sebelum dan sesudah perlakuan pada 
kelompok ASIH maupun kontrol dengan menggunakan uji Wilcoxon didapatkan hasil samasama menunjukkan perbedaan yang bermakna dengan nilai $\mathrm{p}<0,05$. Gambar 4.1 menunjukkan perbedaan skor keluhan nyeri pada kedua kelompok penelitian. Pengamatan sebelum perlakuan median skor VAS dan rentang pada kedua kelompok penelitian tidak menunjukkan ada perbedaan yang bermakna. Setelah perlakuan diberikan baik pada kelompok intervensi maupun kontrol median skor VAS menjadi 2 dengan rentang antara $1-5$

Tabel 4.3 Pengaruh Penerapan ASIH terhadap Penurunan Skor Keluhan Nyeri Pinggang

\begin{tabular}{|c|c|c|c|c|}
\hline \multirow{2}{*}{\multicolumn{2}{|c|}{ Kelompok }} & \multicolumn{2}{|c|}{ Penurunan VAS } & \multirow[b]{2}{*}{ Nilai $p^{*)}$} \\
\hline & & Tidak turun & Turun & \\
\hline 1. & Kontrol & $20(64,5 \%)$ & $11(35,5 \%)$ & 0,042 \\
\hline 2. & ASIH & $12(38,7 \%)$ & $19(61,3 \%)$ & \\
\hline
\end{tabular}

Tabel 4.3 menyajikan penurunan skor keluhan nyeri pinggang (VAS) pada kedua kelompok memiliki perbedaan yang bermakna $(\mathrm{p}<0,05)$. Dimana kelompok ASIH sebanyak 19 orang $(61,3 \%)$ mengalami penurunan; sedangkan pada kelompok kontrol hanya sebanyak 11 orang $(35,5 \%)$ yang mengalami penurunan.

Nilai NTT (Number Need to Treat) untuk keluhan nyeri pinggang dalam penelitian ini berdasarkan tabel 4.3 didapatkan dengan rumus:

$\mathrm{ARR}=\frac{20}{31}-\frac{12}{31}=\frac{8}{31}$
$\mathrm{NNT}=\frac{1}{A R R}=\frac{1}{8 / 31}=\frac{31}{8}=3.875$

Berdasarkan hitungan NNT tersebut, diketahui bahwa diperlukan 4 orang yang diberikan Aplikasi Sahabat Ibu Hamil (ASIH) untuk menurunkan keluhan nyeri pinggang pada 1 orang.

\section{PEMBAHASAN}

\section{Karakteristik Subjek Penelitian}

Pada penelitian ini responden terbanyak berada pada rentang usia 20-35 tahun baik pada kelompok intervensi maupun kelompok kontrol serta tidak berbeda bermakna antara kedua kelompok tersebut. Usia tersebut merupakan kurun usia reproduksi sehat sehingga pada usia tersebut wanita mudah mendapatkan kehamilan. Namun terdapat usia yang $\geq 35$ tahun pada kedua kelompok penelitian. 8 subjek pada kelompok intervensi dan 2 subjek pada kelompok kontrol. Semakin bertambahnya usia dikaitkan akan terjadi penurunan sistem tubuh manusia yang salah satunya adalah muskuloskeletal yang berakibat meningkatnya keluhan pada muskuloskeletal termasuk keluhan nyeri pinggang. Usia juga berkaitan dengan kematangan cara berfikir dalam menyikapi segala hal. semakin banyaknya pengalaman dan informasi yang diperoleh sehingga mampu membangun konsep diri yang baik dan mampu menumbuhkan kepercayaan diri dalam melakukan suatu tindakan.

Karakteristik yang kedua yaitu usia kehamilan, berdasarkan tabel 4.1 menunjukkan karakteristik usia kehamilan subjek penelitian tidak berbeda bermakna pada kedua kelompok penelitian. Usia kehamilan dikaitkan dengan rata-rata skala nyeri pinggang yang dirasakan ibu hamil. Semakin tinggi usia kehamilan, maka semakin tinggi angka terjadinya nyeri pinggang serta rata-rata skala nyeri akhir kehamilan lebih tinggi daripada awal kehamilan. Tahapan trimester kehamilan selanjutnya menyebabkan semakin membesarya uterus, perubahan postural, gravitasi dan muskoloskeletal pada usia kehamilan yang semakin tinggi, sehingga menyebabkan angka terjadinya nyeri tulang belakang dan tingkatan skala kehamilan pada trimester akhir semakin meningkat.

Karakteristik berikutnya adalah paritas subjek penelitian, dari tabel 4.1 menunjukkan bahwa pada karakteristik paritas tidak berbeda bermakna pada kedua kelompok penelitian. Terlihat pada kelompok intervensi dengan primipara sebanyak 12 orang, multipara sebanyak 
19 orang sedangkan pada kelompok kontrol primipara sebanyak 9 orang, multipara 21 orang dan grandemultipara sebanyak 1 orang. Paritas dapat mempengaruhi pilihan ibu dalam melakukan penatalaksanaan terhadap keluhan yang dirasakan selama kehamilan, penentuan pilihan untuk mencari informasi dapat melalui tenaga kesehatan, teman sejawat, orang tua maupun media elektronik (internet). Responden yang hamil pertama dan kedua cenderung mencari informasi melalui media elektronik dan internet sedangkan yang lainnya mencari informasi di tenaga kesehatan dan orang disekitarnya, hanya sebagian kecil yang mencari di media elektronik. Paritas juga dikaitkan dengan sistem tubuh ibu. Paritas yang tinggi akan meningkatkan resiko kejadian nyeri pinggang. Dengan demikian semakin sering seorang wanita hamil dan melahirkan maka resiko terjadinya nyeri pinggang selama kehamilan semakin meningkat. Perubahan muskuloskeletal, tonus otot yang mengalami peregangan pada kehamilan sebelumnya tidak bisa pulih seperti sebelum kehamilan terutama jika setelah masa kehamilan tidak melakukan latihan fisik yang tepat. Akibatnya otot-otot abdomen dan uterus akan mengendur. Otot-otot abdomen wanita menjadi lemah sehingga gagal menopang uterus yang membesar menyebabkan uterus akan mengendur, semakin memanjang. Hal ini akan meningkatkan resiko nyeri pinggang. Kelemahan otot abdomen lebih umum terjadi pada wanita yang terlalu sering hamil (grandemultipara) yang tidak melakukan latihan untuk mengembalikan tonus otot abdomennya tiap kali selesai melahirkan.

Karakteristik selanjutnya yaitu tingkat pendidikan subjek penelitian, berdasarkan tabel 4.1 karakteristik subjek penelitian pada kedua kelompok yang terbanyak adalah SMA, yaitu 27 pada kelompok intervensi dan 25 pada kelompok kontrol. Tingkat pendidikan memengaruhi respon individu terhadap nyeri. Individu yang memiliki tingkat pendidikan tinggi cenderung mempersepsikan nyeri yang lebih berat. Hal ini dikarenakan pada orang yang berpendidikan tinggi dikaitkan dengan kemudahan akses hidup layak sehingga orang yang pendidikan tinggi semakin tidak mentoleransi terhadap nyeri. Tingkat pendidikan juga dikaitkan terhadap pemahaman dalam penerimaan informasi seseorang. Semakin tinggi pendidikan seseorang, semakin mudah pula menerima informasi dan pada akhirnya pengetahuan yang dimilikinya lebih banyak. Jika seseorang memiliki tingkat pendidikan rendah maka akan menghambat perkembangan sikap dan perilaku seseorang terhadap penerimaan informasi dan nilai-nilai yang baru.

Karakteristik selanjutnya adalah pekerjaan subjek penelitian, berdasarkan tabel 4.1 mayoritas ibu hamil tidak bekerja, sebanyak 28 pada kelompok intervensi dan sebanyak 30 pada kelompok kontrol. Pekerjaan secara umum didefinisikan sebagai sebuah kegiatan aktif yang dilakukan oleh manusia Pekerjaan digunakan untuk suatu tugas atau kerja yang menghasilkan sebuah karya bernilai imbalan dalam bentuk uang bagi seseorang. Pekerjaan yang tidak berbeda antara kedua kelompok penelitian menunjukan adanya kesamaan penghasilan yang diperoleh untuk memenuhi kebutuhan hidup sehari-hari, pekerjaan menggambarkan penghasilan sesorang untuk menentukan pilihannya terhadap pelayanan kesehatan yang disediakan. Hal ini menggambarkan pekerjaan seseorang mempengaruhi tinggi rendahnya pendapatan sehingga berdampak terhadap pemilihan pelayanan kesehatan selama hamil. Pekerjaan juga dikaitkan dengan beban kerja yang merupakan aktivitas fisik, mental, sosial yang diterima oleh seseorang yang harus diselesaikan dalam waktu tertentu dalam keadaan normal. Pekerjaan atau gerakan yang menggunakan tenaga besar akan memberikan beban mekanik yang besar terhadap otot, ligamen dan sendi sehingga dapat menimbulkan nyeri pinggang. Sikap yang tidak baik dapat membuat tubuh menjadi cepat lelah, ketegangan otot dan akhirnya menimbulkan rasa nyeri. Pekerjaan dan aktivitas berat juga dapat menyebabkan nyeri pinggang, seperti mengangkat, menarik, mendorong, memutar pinggang, terpeleset, duduk dalam jangka waktu lama, atau terpapar getaran yang lama.

Karakteristik selanjutnya adalah aktivitas sehari-hari subjek penelitian, berdasarkan tabel 4.1 karakteristik akivitas sehari-hari responden tidak berbeda bermakna pada kedua kelompok. 
Hasil penelitian menunjukkan pada kelompok intervensi responden dengan aktivitas sedang sebanyak 27 orang dan aktivitas rendah sebanyak 4 orang, sedangkan pada kelompok kontrol responden dengan aktivitas sedang sebanyak 27 orang dan aktivitas rendah sebanyak 4 orang. Aktivitas sehari-hari ibu yang terlalu berat dapat mengakibatnya terjadinya nyeri pinggang pada kehamilan. Hasil penelitian Nuansa Bunga Atmantika menyatakan melakukan aktivitas berat dan dengan postur tubuh yang salah mengakibatkan otot tidak mampu untuk mempertahankan posisi tulang. Gejala yang ditimbulkan adalah nyeri, spasme otot tulang belakang dan keterbatasan gerakan punggung. Karakteristik selanjutnya adalah weight gain subjek penelitian, berdasarkan tabel 4.1 karakteristik subjek penelitian pada kedua kelompok tidak berbeda bermakna. Hasil penelitian menunjukkan pada kelompok intervensi dengan kategori rendah sebanyak 2 orang normal sebanyak 27 orang dan 2 orang kategori tinggi, sedangkan pada kelompok kontrol sebanyak 9 orang dengan kategori normal dan sebanyak 2 orang dengan kategori tinggi. Peningkatan berat badan seseorang yang berlebih berisiko 5 kali menderita dibandingkan dengan orang yang memiliki berat badan ideal. Ketika berat badan bertambah, tulang belakang akan tertekan untuk menerima beban yang membebani tersebut sehingga mengakibatkan mudahnya terjadi kerusakan dan bahaya pada stuktur tulang belakang. Salah satu daerah pada tulang belakang yang paling berisiko akibat efek dari obesitas adalah vertebrae lumbal.

\section{Pengaruh Penerapan Aplikasi Sahabat Ibu Hamil (ASIH) Terhadap Penurunan Keluhan Nyeri Pinggang Pada Kehamilan Trimester II dan III}

Nyeri pinggang dalam kehamilan merupakan nyeri yang dirasakan di daerah pinggang yang menjalar ke arah tungkai dan kaki terutama bagian belakang. Nyeri yang terjadi dikarenakan pembesaran rahim akibat janin yang semakin membesar, sehingga menekan tulang belakang dan panggul serta merubah postur tubuh ibu menjadi semakin lordosis.

Nyeri pinggang dalam kehamilan merupakah hal yang fisiologi dialami oleh ibu hamil. Banyak faktor yang memengaruhi nyeri pinggang dalam kehamilan. Pada penelitian ini faktor yang memengaruhi nyeri pinggang dari faktor fisiologis seperti usia ibu, usia kehamilan, paritas, weight gain, aktivitas ibu, tingkat pendidikan dan pekerjaan tidak terdapat perbedaan bermakna ( $>$ >0,05) baik pada kelompok ASIH maupun kelompok kontrol.

Secara statistik, hasil penelitian perbedaan kategori nyeri pinggang sebelum dan sesudah diberikan intervensi pada kedua kelompok menunjukkan tidak terdapat perbedaan bermakna. Pada tabel 4.2 tampak tidak terdapat perbedaan bermakna pada kedua kelompok dengan nilai $\mathrm{p}<0,05$. Hal ini dikarenakan hasil pengukuran nyeri menggunakan Visual Analog Scale (VAS) dengan kategori yang didasarkan pada subjektifitas keluhan yang dirasakan ibu hamil. Meskipun terjadi penurunan secara numerik, namun belum tentu terjadi penurunan secara kategori. Hal ini juga disebabkan karena intensitas nyeri yang digunakan pada penelitian ini hanya intensitas nyeri ringan dan sedang, meskipun terjadi penurunan namun perbedaan intensitas nyeri sebelum dan sesudah diberikan intervensi tidak signifikan.

Namun secara statistik hasil penelitian menunjukan bahwa Aplikasi Sahabat Ibu Hamil (ASIH) dapat menurunkan skor keluhan nyeri pinggang pada kehamilan trimester II dan III. Pada tabel 4.4 menunjukkan hasil analisis statistik diperoleh nilai $\mathrm{p}=0,042(\mathrm{p}<0,05)$. Hasil pengukuran nyeri menggunakan Visual Analog Scale (VAS) intensitas nyeri numerik. Penelitian ini sejalan dengan penelitian oleh Pamela portelli, dkk yang menyatakan bahwa penggunaan smartphone dapat digunakan sebagai pengelolaan rasa nyeri dengan memberikan terapi perilaku kognitif sehingga pasien lebih dapat menerima dengan meningkatkan keterlibatan dalam strategi pengelolaan rasa nyeri itu sendiri.

Salah satu fungsi Penggunaan aplikasi mobile phone (mHealth) yang diidentifikasi oleh World Health Organization (WHO) adalah bertujuan untuk memberikan pendidikan kesehatan dan perubahan perilaku kesehatan. Mobile health dapat meningkatkan pengetahuan, 
mempengaruhi sikap dan mengubah perilaku pasien terhadap kesehatannya, sehingga meningkatkan status kesehatan. Mobile Health dapat mencegah terjadinya komplikasi kehamilan dan hasil obstetri yang merugikan. Memanfaatkan media Aplikasi Sahabat Ibu Hamil (ASIH) dalam panduan mengatasi keluhan nyeri pinggang dapat meningkatkan menurunkan keluhan ibu hamil, ibu hamil dapat mengakses informasi, sehingga pengetahuan ibu hamil meningkat. Pengetahuan merupakan modal awal bagi terbentuknya sikap yang akhirnya akan mengarah pada niat akan melakukan perbuatan atau tindakan. Hal ini sesuai dengan penelitian Mark V Williams yang menyebutkan bahwa pemanfaatan teknologi mobile health mengakibatkan peningkatan pengetahuan tentang perawatan kehamilan bagi ibu hamil, mempengaruhi sikap dan perubahan perilaku sehingga pada akhirnya meningkatkan kesehatan bagi ibu dan bayi.

Penggunaan media akan membantu memperjelas informasi yang disampaikan, karena lebih menarik, lebih interaktif, dapat mengatasi batasan ruang, waktu dan indera manusia. Agar informasi yang disampaikan lebih jelas dan mudah dipahami sesuai dengan tujuan yang akan dicapai, maka informasi tersebut dikemas sesuai dengan karakteristik dari setiap media yang digunakan. Penggunaan media dapat meningkatkan pengetahuan, keterampilan, sikap dan perilaku dari hasil proses. Keberhasilan ditentukan efektivitas media dan penggunaan media pemberian informasi sangat ditentukan oleh olah banyaknya indra yang digunakan.

Aplikasi Sahabat Ibu Hamil (ASIH) merupakan media pemberian informasi dilengkapi tampilan yang berisi tentang informasi penanganan keluhan ibu hamil berdasarkan data fokus, kebutuhan dasar ibu hamil, deteksi dini komplikasi kehamilan dan tanda bahaya ibu hamil. ASIH dilengkapi gambar-gambar yang menarik dan edukatif, sehingga ibu hamil tertarik untuk untuk membacanya dan mudah diakses. Aplikasi ini dapat dioperasikan secara online maupun offline. Keunggulan ASIH adalah ibu hamil dapat melakukan penatalaksanaan tentang keluhan salah satunya nyeri pinggang. Hal ini sesuai penelitian Lina Erviana, dkk yang menyatakan bahwa penerapan media gambar animasi dan media gambar statis dapat mempermudah proses belajar dan meningkatkan pemahaman. Selain itu animasi komputer mempunyai aspek kesederhanaan, dinamis, lebih menarik, tidak membosankan, mengandung nilai, dan mudah dipahami. Hasil penelitian lain oleh Nurul Lolona Lingga yang menyatakan bahwa penggunaan animasi dan gambar memiliki kelebihan dibandingkan dengan media lain yaitu informasi yang didapatkan dari gambar tersimpan pada memori jangka panjang.

ASIH sebagai panduan penganan keluhan nyeri pinggang merupakan teknik distraksi untuk mengurangi keluhan nyeri. Distraksi mengalihkan perhatian ibu hamil dengan keluhan nyeri pinggang ke hal yang lain dan dengan demikian menurunkan kewaspadaan terhadap nyeri bahkan meningkatkan toleransi terhadap nyeri. Menurut Muttaqin (2011), distraksi (pengalihan perhatian) dapat menurunkan stimulus internal dengan mekanisme peningkatan produksi endorfin dan enkefalin yang dapat memblok reseptor nyeri agar tidak dikirimkan ke kortek serebri sehingga menurunkan persepsi nyeri.

Melalui penelitian ini bahwa ASIH sebagai media pendidikan kesehatan ibu hamil trimester II dan III berpengaruh menurunkan keluhan nyeri pinggang pada ibu hamil. Dengan tampilan yang menarik berupa gambar-gambar mempermudah proses belajar dan meningkatkan pemahaman ibu hamil menjadikan ASIH sebagai aplikasi yang memudahkan ibu sebagai panduan dalam penanganan keluhan nyeri pinggang, sehingga ibu dapat mengelola rasa nyeri dengan baik dan menjalani kehamilan dengan sehat dan lancar.

\section{DAFTAR PUSTAKA}

1. Supartono. Pengukuran tingkat kepuasan pelanggan. Jakarta: Rineka Cipta; 2006.

2. RI K. Kesehatan Dalam Kerangka Sustainable Development Goals (SDGS). 2015.

3. Indrayani, editor. Buku Ajar Asuhan Kehamilan. Jakarta: Trans Info Media; 2011. 
4. Irianti B, Halida EM, Duhita F, Prabandani F, Yulita N, Hartiningtyaswati S, dkk. Asuhan Kehamilan Berbasis Bukti. 1, editor. Jakarta: Sagung Seto; 2014.

5. Walsh LV. Buku Ajar Kebidanan Komunitas. Jakarta: EGC; 2007.

6. Varney H. Buku Ajar Asuhan Kebidanan Vol. I. Jakarta: EGC; 2006.

7. Nazik E, Eryilmaz G. Incidence of pregnancy-related discomforts and management approaches to relieve them among pregnant women. Journal of Clinical Nursing. 2013 12:1-15.

8. Marniyati L, Saleh I, Soebyakto BB. Pelayanan Antenatal Berkualitas dalam Meningkatkan Deteksi Risiko Tinggi pada Ibu Hamil oleh Tenaga Kesehatan di Puskesmas Sako, Sosial, Sei Baung dan Sei Selincah di Kota Palembang. Jurnal Kedokteran dan Kesehatan. 2016;3(1):355.

9. Afiyanti Y. Studi Fenomenologi Tentang Pengalaman Wanita Di Daerah Pedesaan Dalam Menjalani Masa Kehamilan Pertama. Jurnal Keperawatan Indonesia. 2004;8(2):62-9.

10. Sistiarani C, Gamelia E, Sari DUP. Fungsi Pemanfaatan Buku KIA terhadap Pengetahuan Kesehatan Ibu dan Anak pada Ibu. Jurnal Kesehatan Masyarakat Nasional. 2014;8(8):3538.

11. Zainal Y, Sanjaya GY, Hasanbasri M. Perlunya Sistem Informasi Dalam Mengelola Data Rutin Untuk Monitoring Kesehatan Ibu dan Anak. Seminar Nasional Sistem Informasi Indonesia. 2013 4:273-9.

12. Oktarina, Mugeni. Hubungan Pengetahuan, Sikap, Kepatuhan Ibu Hamil dan Ibu Bayi Dalam Penggunaan Buku KIA Di Puskesmas Geger dan Kedundung Kabupaten Bangkalan, Jawa Timur Tahun 2013. Buletin Penelitian Sistem Kesehatan. 2015 8;18(21):141-50.

13. Masruroh. Hubungan Pengetahuan Ibu Hamil Tentang Ketidaknyamanan Kehamilan Dengan Sikap Mengatasi Ketidaknyamanan Kehamilan Di Puskesmas Tulis I Kec. Tulis Kab. Batang. Jurnal Ilmiah Kesehatan Akbid Uniska Kendal. 2012;1:1-10.

14. Smith DK, Slack J, Shaw RW, Marteau TM. Lack of knowledge in health professionals: a barrier to providing information to patients. Quality in Health Care. 1994 23;3:75-8.

15. Hildingsson I, Haines H, Cross M, Pallant JF, Rubertsson C. Women's satisfaction with antenatal care: Comparing women in Sweden and Australia. Women and Birth. 2013 22;26:e9-e14.

16. Melay SR, Asnindari LN. Hubungan Kualitas Pelayanan Antenatal Care (ANC) dengan Kepuasan Ibu Hamil Terhadap Pelayanan ANC Di Puskesmas Mergangsan Tahun 2013. 2013:1-13.

17. Hutagaol EE, Agustin H. Komunikasi Interpersonal Petugas Kesehatan Dalam Kegiatan Posyandu Di Wilayah Kerja Puskesmas Muara Siberut Kabupaten Mentawai. Jurnal Kesehatan Masyarakat 2012;6(2):104-12.

18. Maria A. Sikap dan Komunikasi Bidan Terhadap Tingkat Kepuasan Ibu Hamil Pada Pelaksanaan Antenatal Care. Jurnal Vokasi Kesehatan. 2015;1(5):136-41.

19. Lund S, Nielsen BB, Hemed M, IdaMBoas, Said A, Said K, et al. Mobile phones improve antenatal care attendance in Zanzibar: a cluster randomized controlled trial. BMC Pregnancy and Childbirth. 2014;14(29):1-10.

20. Jareethum R, Titapant V, Tienthai C, Viboonchart S, Chuenwattana P, Chatchainoppakhun J. Satisfaction of Healthy Pregnant Women Receiving Short Message Service via Mobile Phone for Prenatal Support: A Randomized Controlled Trial. Med Assoc Thai 2008;91(4) 